\title{
Anadolu'da Aydınlanma Hareketinin Doğuşu: Köy Enstitüleri
}

\author{
Dr. Necdet AYSAL ${ }^{*}$
}

\section{ÖZET}

Köy Enstitüleri, Cumhuriyet aydınlanmasının eğitim alanındaki en özgün ve en çok ses getiren bir uygulamasıdır. Hazırlıkları 1935'te başlatılıp 1937'de denemesine girişilen enstitülerin, 1940'da yasal bir zemine oturtulduğu görülmektedir.

17 Nisan 1940'da kabul edilen 3803 sayılı Köy Enstitüleri Kanunu'na göre, enstitülerin görevi sadece köy öğretmeni yetiştirmekle sinırlı kalmayıp, öğretmenle birlikte sağllk görevlileri, teknisyenler gibi meslek elemanları yetiştirmekti. Köy Enstitüleri, kuruluş amaçlarının çok üstünde bir başarı göstermişlerdir. Köyün, kırsal alanlarda yaşayanların sorunlarını ortaya koyan ilerici bir kuşă̆ın yetişmesini sağlamışlardır.

Bu çalışmamızda Köy Enstitüleri'nin kuruluş amaçları ve etkinlikleri vurgulanacak, Enstitülerin kapatılmasına yol açan olumsuz propaganda ve eleştiriler üzerinde durulacaktır.

Anahtar Kelimeler: Köy Enstitüleri, Cumhuriyet Halk Partisi, Demokrat Parti, Hasan Âli Yücel, İsmail Hakkı Tonguç, Saffet Arıkan, Reşat Şemsettin Sirer, Tahsin Banguoğlu, Tevfik İleri.

\section{The Born Of Illumination Movement In Anatolia: Village Institutes \\ ABSTRACT}

Village Institutes are the most original and useful practice of Republic illumination. Preparation of Village Institutes started in 1935 and practices were began in 1937. In April 17th, 1940, it settled on a legal basement with the low \#3803.

· Ankara Üniversitesi Türk Inkilap Tarihi Enstitüsü, Öğretim Görevlisi. 
According to the low, village institutes are not limited only to education of the teacher for their village, beside the teachers, they also give education for the medical employees, technicians etc. Village Institutes are over successful then their target of foundation. They also provided the grew a young population to help the problems of the people who live in country.

We will point out the target of foundation and activities of the Village Institutes, also prevent the criticism and the negative propagandas about to close of the village Institutes.

Key Words: Village Institutes, People of Republic Party, Democrat Party, Hasan Âli Yücel, İsmail Hakkı Tonguç, Saffet Arıkan, Reşat Şemsettin Sirer, Tahsin Banguoğlu, Tevfik Illeri.

\section{Giriş}

Türk Milli Eğitimi, Türk Milleti’nin daha güçlü, daha refahlı olmasında ve kişilerin mutluluğunda Atatürkçülüğün bir bütün olarak anlaşılıp uygulanmasında, Türk Devleti'nin milli davalarının, ideolojisinin anlaşılıp anlatılmasında, kuşaktan kuşağa iletilmesinde temel faaliyetleri kapsayan bir sistemdir. Atatürk, Yeni Türk Devleti'nin temellerinin atılmaya başladığı Kurtuluş Savaşı'nın ilk yıllarında bile, ülkeyi çağdaş medeniyete ulaştıracak Milli Eğitim sistem ve kurumlarını araştırmaya başlamıştı. Ulusal Bağımsızlık Savaşı'nın en buhranlı günlerinde 16 Temmuz 1921'de Ankara'da Maarif Kongresi'nin (Milli Eğitim Şurası) toplanması bunun kanıtıdır'. Söz konusu kongreyi açış konuşmasında eğitimi, milletleri uygarlığa götüren ve Türk Devleti'ni dinamik idealine ulaştıracak bir araç olarak yorumlayan Atatürk, konuşmasına şu sözlerle devam etmiştir:

“... Devlet bünyesinde yüzyıllar boyu derin idari ihmallerin neden olduğu yaralarl iyileştirmede verilecek emeklerin en büyüğünü hiç kuşku yok ki, irfan yolunda esirgemememiz lazımdır... Şimdiye kadar takip olunan öğretim yöntemlerinin, milletimizin gerileme tarihinde önemli etken olduğu kanaatindeyim. Onun için bir Milli Ĕ̆itim Programi'ndan söz ederken, eski devrin boş inançlarından ve yaradılış niteliklerimizle hiç de ilgisi olmayan yabancı fikirlerden, doğudan ve batıdan gelebilen bütün etkilerden tamamen uzak, milli karakterimiz ve tarihimizle uyumlu kültür kastediyorum. Çünkü, milli dehamızın tam olarak gelişmesi, ancak böyle bir kültürle sağlanabilir. Herhangi bir yabanct kültür, şimdiye kadar takip edilen yabanct kültürlerin yıkıcı sonuçlarını tekrar ettirebilir. Fikri kültür ortamla uyumludur. O ortam milletin karakteridir..."

Mustafa Kemal Atatürk'ün, eğitim teşkilatının esaslarını ve verimli bir çalışma sağlayacak ilkelerin hazırlanması gerektiğini vurgulayan

'Esengül Balcı Bucak, Türkiye'nin Eğitim Politikaları ve Siyasi Parti Ödülleri, Ankara, Adım Yayınlan, 1993, s. 118. 
konuşmasına, Ulusal Bağımsızlık Savaşı'nın hemen sonunda da "Milletimizi gerçek saadete ulaştıracak irfan ordusudur" diyerek eğitime verdiği önemi vurgulaması son derece önemlidir ${ }^{2}$. Henüz Ulusal Bağımsızlık Savaşı'nın sona ermediği ve Lozan Antlaşması'nın imzalanmadığı günlerde Anadolu'da bir yurt gezisine çıkan Atatürk halka şunları söylemektedir"

"Arkadaşlar! Bundan sonra pek mühim zaferlere kavuşacă̆ız. Fakat bu zaferler süngü zaferleri değil, iktisat ilim ve irfan olacaktrr. Ordumuzun şimdiye kadar kazandı ğı zaferler, memleketimizi gerçek kurtuluşa kavuşturmuş sayılmaz. Bu zaferler ancak gelecek zaferlerimiz için değerli bir zemin hazırlamıştır. Askeri zaferlerimizle mağrur olmayaltm. Yeni ilim ve iktisat zaferlerine hazırlanalım."

$\mathrm{Bu}$ sözlerle, milleti gerçek zafere eğitimin kavuşturacağını ifade eden Mustafa Kemal, gençleri ise geleceğin teminatı olarak görmektedir. Bunun yanı sıra Atatürk, 1 Mart 1922'de TBMM'ni açarken yapmış olduğu söylevde, ne ulusal ne de dünya tarihinde benzerine rastlanılmayan bir gerçeklik ve sertlikle, Anadolu köylüsünün durumunu açıklıyor ve devletin ona karşı olan ödevlerine dikkat çekiyordu ${ }^{4}$ :

"Yüzyıllardan beri ulusumuzu yöneten hükümetler öğretim ve eğitimin genelleşmesi isteğini göstere gelmişlerdir. Ancak bu isteklerine varmak için Doğuyu ve Batıyı yansılamaktan (taklitten) kurtulamadıklarından sonuç ulusumuzun bilgisizlikten kurtulamamasına varmıştır. Bu acıklı gerçek karşısında bizim izlemek zorunda olduğumuz eğitim ve öğretim siyasasının ana çizgileri şöyle olmalıdır... demiştim ki, bu yurdun asll sahibi ve toplumumuzun temel öğesi köylüdür. İste bu köylüdür ki bugüne dek eğitim ve öğretim ışı̆̆ından yoksun bırakılmıştır...

"Türkiye'nin asıl sahibi ve efendisi kimdir? Bunun yanttın hemen birlikte verelim. Türkiye'nin asıl sahibi ve efendisi, gerçek üretici olan köylüdür. Öyle ise herkesten daha çok gönence, mutluluğa ve zenginliğe en çok hak kazanan ve lâylk olan köylüdür. Bunun için TBMM Hükümeti'nin iktisadi yasası bu temel ereği elde etmeye yöneliktir..."

Türk milletinin çağdaş uygarlık düzeyine ulaşması amacıyla yapılan devrimler arasında, 1 Kasım 1928'de yeni Türk harflerinin kabul edilmesiyle tüm yurtta hummalı bir faaliyete girişilmişti. Herkesin okuma ve yazma öğrenmek istemesi üzerine, Cumhurbaşkanı Mustafa Kemal Paşa'nın gayretleriyle millet mektepleri açılmıştı. Mustafa Necati (Uğural) Bey'in

${ }^{2}$ Genelkurmay Başkanlığı, Atatürkçülük, Atatürkçü Düşünce Sistemi, İstanbul, Milli Eğitim Bakanlığı Yayınları, 1998, s. 129-130; TBMM Zabıt Ceridesi, I. Dönem, 3. Toplantı. C. 188, s. 5 .

'İhsan Doğramacı, "Atatürk ve Eğitim”, Atatürk Araştırmaları Merkezi Dergisi, C. I, No 3 , s. 656.

${ }^{4}$ Rauf İnan, "Türkiye Cumhuriyeti ve Eğitim-Bir Yokluktan Bir Atılıma", Atatürk Konferanslarl (1973-1974), Ankara, TTK, 1977, s. 245. 
Milli Eğitim Bakanlığı döneminde açılışı gerçekleşen bu okullarda [1 Ocak 1929], okuma-yazma bilenlere yeni harflerle okuma-yazma öğretmek hedeflenmiști'. Ayrıca, cahilliğe karşı açılan bu savaşın 1932'de "Halk Evleri"nin kurulmasıyla yeni bir güç kazandığı da görülecektir. Kuruluş amac1, halkı salt okuryazarlıkta, temel bilgilerde değil, kültürel toplumsal ve güzel sanatlar alanında geliştirmek, ulusal değerleri çă̆daş yöntemlerle işleyip zenginleştirmek ve Atatürk devrim ve ilkelerini yaymak ve kökleştirmek olarak açıklanmaktadır. Atatürk, Türk milletinin kadın-erkek, zengin fakir ayırt etmeden bir bütün halinde eğitim imkânı veren bir kültür ve eğitim merkezini gerekli görmüş, Türk Ocakları ve Öğretmen birliklerini de içinde toplayan halkevlerini 19 Şubat 1932'de 14 il merkezinde kurdurmuștur ${ }^{6}$. Halkevleri, halkçıllık politikasının somut bir denemesi olarak ortaya çıkmış ve aynı tarihte Halk Partisi Genel Sekreteri Recep (Peker) Bey, açllış töreni münasebetiyle şöyle bir konuşma yapmıştır": "Arkadaşlar, biz halkevlerinin samimi ve bütün Türk vatandaşlarını müsavi şeref mevkiinde gören zihniyetle kurulmuş çatılar altında bütün vatandaşları toplamaya ve itinalı bir kültür çalışması içinde milli birliğe yükseltmeye azmetmiş bulunuyoruz..." Halkevleri sosyo-kültürel gelişmeyi hızlandıran, halkı ortaçağ karanlığından kurtarmayı amaçlayan kurumlardı‥ Genç aydınların tamamen özverili çalışmaları Halkevlerinin kısa sürede gelişmesine neden olmuş ve folklorcular, tarihçiler, sosyologlar halkevleri faaliyeti içinde köyleri de inceleme fırsatı bulmuşlar, ancak şehirlerde elde edilen başarılar köylerde alınamamış, bu durum ise dikkatlerin köylere çekilmesine sebep olmuştur.

\section{Enstitülerin Kuruluş Amaçları}

1935 yılına gelindiğinde ülke nüfusunun yüzde sekseninin yaşadığı köylerde okul sayısı yok denilecek kadar azdır. Bu okullara kentlerden bulunup gönderilen az sayıda öğretmen de, köylerde tutunamamakta ve başarılı olamamaktadır. Köy insanının eğitim gereksinmesi sadece okuryazarlıkla sınırlı değildir; bulaşıcı hastalıklarla savaşamamakta, üretimini ilkel yöntemlerle yapmaktadır. Ulusal Bağımsızlık Savaşı'nın ağır yükünü çeken köylüler, henüz demokrasiyi yaşatacak cumhuriyet yurttaşı niteliğine kavuşamamıştır. Asıl önemlisi, 1930-1940 yılları arasında köye hizmet götürmek çok zordur. Cumhuriyetle birlikte girişilen köye hizmet çabaları; ya köylünün beklentilerine uymadığı ya da becerilemediği için yarım kalmıştır. Başarı için köylünün dilinden anlayan yeni bir aydın tipine gereksinme vardır. Bu da köylünün kendi içinden çıkabilecektir. İşin bu püf noktasını iyi yakalayan ve kendisi de bir köylü çocuğu olan büyük eğitimci

${ }^{5}$ Necdet Sakaoğlu, Cumhuriyet Dönemi Eğitim Tarihi, İstanbul, Cep Üniversitesi İletișim Yayınları, 1993, s. 46.

${ }^{6}$ Şevket Gediklioğlu, Türkiye'de Yaygın Eğitimden Çağdaş Eğitime, Ankara, Kadıŏlu Matbaası, 1991, s. 11-15.

${ }^{7}$ Anıl Ceçen, "Halkevleri", Atatürk ve Halk Evleri, Ankara, TTK Yay., 1974, s. 89.

${ }^{8}$ Hakimiyet-i Milliye Gazetesi, 20 Şubat 1932, s. 2.

${ }^{9}$ Çeçen, s. 89-91. 
İsmail Hakkı Tonguç Bey, Köy Enstitüsü sisteminin hem kuramcısı hem de kurucusu olacaktır. Onu Atatürk'ün eski kurmaylarından Milli Eğitim Bakanı Saffet Arıkan göreve getirmiş, sonraki Bakan Hasan Ali Yücel de onun bu girişimlerine sahip çıkmıştır. İsmail Hakkı Tonguç Bey'in, köy sorununa ve köylünün kurtuluşuna bakış açısını şöyle özetlemek mümkündür ${ }^{10}$ :

"Köy meselesi bazılarının zannettikleri gibi mihaniki surette köy kalkınması değil, manalı ve şuurlu bir şekilde köyün içten canlandırılmasıdır. Köy insanı öylesine canlandırtmalı ve şuurlandırılmalı ki, onu hiçbir kuvvet yalnız kendi hesabına ve insafsızca istismar etmesin. Ona esir ve uşak muamelesi yapamasın. Köylüler şuursuz ve bedava çalışan birer iş hayvant haline gelmesinler. Onlar da her vatandaş gibi, her zaman haklarına kavuşabilsinler. Köy meselesi, köyde eğitim problemleri de içinde olmak üzere bu demektir...

“Köylüyü, köyden başlayarak ta Kamutay'a [TBMM] varıncaya kadar, devletin bütün şubelerinin idaresine, onda bugünkü vasıflardan başka bir şart aramaksızın iştirak ettirmek, bu suretle devlet işlerini, realiteden kuvvet alan elemanlarla besleyerek memleketin hakiki bünyesine uygun bir şekle getirmek... köylü vatandaşlarda... Cumhuriyet vatandaşlı̆̆ı şuurunu, aksiyon haline gelebilecek şekilde uyandırmak.... lâzımdır..."

Cumhuriyet Halk Partisi'nin 1935 yilında gerçekleşen Büyük Kurultayı'nda, devlet eliyle başlatılan planlı endüstrileşme hareketine koşut olarak, planlı köyleri kalkındırma hareketinin başlatılması kararlaştııılmıștır. $\mathrm{Bu}$ arada Milli Eğitim Bakanlığına getirilen Saffet Arıkan", eğitimcilerden özellikle Cevat Dursunoğlu'nun onayını alarak İsmail Hakkı Tonguç'un İlköğretim Genel Müdürlügü’ne atanmasını gerçekleştirmiştir.

İsmail Hakkı Tonguç, önce ciddi bir köy incelemesi yaparak rakamları ve eski yapılanları değerlendirmiş, 20 yıllık bir plan taslağı hazırlamıștır. Bu plana göre 1954 yılına kadar öğretmen, koruyucu, tarım teknisyeni ve sağlık hizmeti ulaşmamış köy kalmayacaktır. Fakat bu planı gerçekleştirmek hiçte kolay olmayacaktır. Her şeyden önce açılacak enstitülere okuryazar köy çocuğu ve öğrenci bulmak büyük sorundu ${ }^{12}$. Tonguç, klasik eğitimcilerin direnişlerine karşın ilk olarak askerliğini yapmış okuryazar gençlerden seçtiği bir grubu, "eğitmen" sanıla köylerde "geçici öğretmen" olarak görevlendirmek amacıyla, 1936 yılında Eskişehir'in Çifteler Çiftliği’nde dört

${ }^{10}$ İsmail Hakkı Tonguç, Illköğretim Kavramı, s. 212.

"Saffet Arıkan (1888-1947), Erzincan doğumlu olup, Harbiye ve Harp Akademisi'ni bitirdikten sonra 1911'de Kurmay Yüzbaşı olarak Yemen'de komutanlık yapmıștır. Canakkale ve Kurtuluş Savașı'na katılan Arıkan, Berlin Büyükelçiliği'nde de bulunmuş ve 1935-1938 yılları arasında Milli Eğitim Bakanlığı yapmıştır. Bkz. Sorguç, s. 54. 112 .

${ }_{12}$ Pakize Türkoğlu, Tonguç ve Enstitüleri, İstanbul, Yapı ve Kredi Yayınları, 1997, s. 
aylık bir kurs açmıştır. Bu kursları tamamlayarak Ankara köylerinde görevlendirilen ilk 84 eğitmen son derece başarılı olmuş ve eğitmen kursları kısa süre içinde ülkenin başka yerlerinde de açılarak çoğaltılmıştır. Eğitmen adayları, açılacak Köy Enstitülerinin ilk binalarını da yapmışlardır. Kendi köylerine giden eğitmenler, topladıkları çocukları üç yıl okutup mezun ederek yenilerini almak, köyde çıkan sağlık sorunlarını kaymakamlığa iletmek, köylüye modern tarım tekniklerini öğretmek, akşam okulları ile yetişkinlere okuma-yazma, hesap ve yurttaşlik öğretmekle de yükümlü tutulmuşlardı.

$\mathrm{Bu}$ ilk uygulamadan olumlu sonuç alınınca, 11 Haziran 1937'de çıkartılan "Köy Eğitmenleri Kanunu" ile eğitmenliğe yasal işlerlik kazandırılmıştır. Bu yasaya dayanılarak Çifteler (Eskişehir), Kızılçullu (İzmir) ve Karaağaç (Edirne)'ta birer eğitmen kursu açılmış ve ertesi yıl bunlara üç yeni kurs daha eklenmiştir ${ }^{13}$. Fakat zamanla eğitmen kursları ile köylerde ilkokul düzeyinde bir öğretimin sürdürülemeyeceği düşünülerek 3704 sayılı yasa ile "Köy Ö̆gretmen Okulları"nın açılması öngörülmüştür. Bununla birlikte köy enstitülerine temel oluşturan başta Kızılçullu, Çifteler ve Gölköy Eğitmen Kurslarının, Köy Öğretmen Okulu'na dönüştürüldüğü görülecektir ${ }^{14}$.

Köy eğitmen kursları ve köy öğretmen okullarının başarılı olması, artık eğitimde nasıl bir yol izlenmesi gerektiğini açıkça ortaya çıkarmıştı. Köy Enstitülerinin kuruluş aşamasında Cumhuriyetimizin kurucusu Gazi Mustafa Kemal Atatürk, uzun süredir çekmekte olduğu hastalığa yenik düşmüş ve 10 Kasım 1938'de vefat etmişti. O büyük kayıp sonrasında silah ve dava arkadaşları, Cumhuriyetin ikinci adamı İsmet İnönü'yü Cumhurbaşkanı seçmişlerdi. İsmet İnönü de Atatürk'ün başlattığı eğitim seferberliğinin devam edeceğini ve köylerde eğitimin aksamayacağını çeşitli konuşmalarında dile getirmektedir.

İsmet İnönü'nün Cumhurbaşkanı seçilmesinden 1,5 ay sonra, Celâl Bayar kabinesinde Milli Eğitim Bakanı olan Saffet Arıkan'ın sağlık nedenlerinden dolayı bakanlıktan ayrılması üzerine, yerine 28 Aralık 1938'de Hasan Âli Yücel atanmıştır. Hasan Âli Yücel, İsmail Hakkı Tonguç'a başladığı işleri birlikte sürdürmelerini rica etmiş ve Tonguç da İlköğretim Genel Müdürü olarak Hasan Âli Yücel'in yanında yer almıștır ${ }^{15}$. Sistem üzerinde anlaşan Bakan Yücel ${ }^{16}$ ile Genel Müdür Tonguç,

\footnotetext{
${ }^{13}$ Şerafettin Turan, Türk Devrim Tarihi, 4. Kitap, Ankara, Bilgi Yayınevi, 1999, s. 40.

14 Turan, s. 40 . 133.

${ }^{15}$ Pakize Türkoğlu, Tonguç ve Enstitüleri, İstanbul, Yapı ve Kredi Yayınları, 1997, s.

${ }^{16}$ Hasan Âli Yücel (1897-1961), Türk eğitimci, yazar ve siyaset adamıdır. 1921'de Edebiyat Fakültesi'nde Felsefe bölümünü bitiren Yücel, çeşitli okullarda öğretmenlik yapmış ve 1935 'te İzmir Milletvekili seçilerek TBMM'ye girmiştir. 1938-1946 yılları arasında Milli Eğitim Bakanlığı yapmıștır. Bu görevi sırasında köy enstitülerinin kurulmasında, teknik öğretimin gelişmesinde etkin roller üstlenmiștir. Bkz. Mustafa Çıkar, Hasan Ali Yücel ve Türk Kültür Reformu, Ankara, Türkiye İş Bankası Kültür Yayınları, 1997; Rauf İnan,
} 
Cumhurbașkanı İnönü'nün de desteğini alarak bașlatılan çalıșmaları hızlandırmışlardır. İsmet İnönü, köy eğitimi konusundaki düşüncelerini şöyle açıklamaktadır ${ }^{17}$ :

“...̇lköğretim konusunda milletçe işbirliği yaptlması, $X X$.

yüzyllın ileri ve güçlü bir milleti olabilmek için mutlaka ilköğretim sorununun çözülmesi, seferberliğe en uzak köyden başlanması, devlet bütçesinin bu iş için yeterli olmadı̆̆ı ancak az masrafla çok öğrenci okutacak bir yöntem bulunmast, konuyla ilgili esaslar gösterilir ise bunlardan faydalanabilecekleri...".

17-29 Temmuz 1939 Birinci Maarif (Eğitim) Şûrası'nda ele alınan bu konu her yönüyle tartışılmaya açılmıştır. Ancak köylünün eğitiminde yalnızca köylüye okuma-yazma öğreten bir öğretmenin yeterli olmayacağı, köy öğretmeni yetiştirecek kurumların çok yönlü eleman yetiştirmesi gerektiğine karar verilerek, yeni açılacak kurumlara “Köy Enstitüsü” adının verilmesi uygun bulunmuştur ${ }^{18}$.

\section{Enstitülerin Etkinlikleri}

İlköğretim sorununu, bir insan ve ulus olma sorunu olarak gören Cumhurbaşkanı İnönü, yeni uygulamaya desteğini verirken şu değerlendirmeyi yapmıştı1": "Illköğretimi olmayan memlekette Ortaçă̆ yönetimi bütün şekilleriyle devam eder... Hür vatandaşlardan birleşik bir ulus olmanın çarelerinin başında ilköğretim çaresi gelir... İlköğretim sorunu, insan olmak, ulus olmak sorunudur." Nitekim, Köy Enstitülerinin kurulmasına ilişkin yasa tasarısı, 17 Nisan 1940'da TBMM'ne sunulmuş ve komisyonun önerisi üzerine ivedilikle görüşülmesine başlanmıştır. Tasarının uzun bir gerekçesi vardır. Bu gerekçede öne çıkan bazı noktalar ise şunlardır ${ }^{20}$ :

"ilköğrenim yapmak zorunda olan çocukların sehir ve kasabalarda \%80'i, köylerde ise \%20'si okutulabilmektedir. Şimdiye kadar köy okullarımızın çoğu üç yıllık ilkokullardı. Onun için bu okullara giden öğrenci de normal beşs sinfll ilkokulu bitiremiyordu. Bu durum, ilköğrenim görmek ya da bu öğrenimi tamamlamak zorunluluğunda olan çocukların büyük çoğunluğunun köylerde olduğunu ve ilköğrenimi yayma işine köylerimizin önemle konu olmast gerektiğini gösterir... 40.000 köyün ancak 4959'unda ögrretmenli ve 4.000'inde eğitmenli okulumuz vardır. 31.000 köyümüz okulsuzdur. Şimdiye kadar köylere hep büyük şehirlerde kurulmuş olan öğretmen

Atatürkçü Destansal Milli Eğitim Bakanı Hasan Âli Yücel, I. B., Ankara, Eğit-Der. Yayınları, 1995, s. 13-25.

17 Cumhuriyet Gazetesi,"Köy Enstitüleri ve Açılacak Yerler”, Yı1: 16, No. 6727 (18 Nisan 1940), s. 1 .

${ }_{18}^{1}$ İsmail Hakkı Tonguç, İlköğretim Kavramı, İstanbul, Remzi Kitabevi, 1946, s. 319.

${ }^{19}$ Turan, s. 41 .

${ }^{20}$ Tevfik Çavdar, Türkiye'nin Demokrasi Tarihi 1839-1950, 2. B., Ankara, İmge Kitabevi, 1999, s. 373-374. 
okullarında yetiştirdiğimiz şehirli gençleri yolladık... Bu kuruluşlardan yetişen öğretmenlerimizin köy koşullarına gereği gibi uymadıkları görülmüştür. Geleceğin köy öğretmenlerini, görecekleri hizmetin gereklerine daha uygun şekil ve koşullar altında yetiştirmek zorunda bulunmaktayız. Bu nedenle köye öğretmen yetiştirmede şu ilkelere uyulur: 'Öğretmen adayını köyden almak, köyden alınmış çocukları köy hayatından uzaklaştırmayan bir çevrede iyi bir çiftçinin bilgilerine sahip ve bildiklerini uygulayabilecek bir halde yetiştirmek, bu çocuklara öğretmenlik mesleği ile birlikte köyde geçecek demircilik, yapıcılık, kooperatifçilik; kız öğrencilere çocuk bakımı, dikiş, ev idaresi gibi işleri öğretmek, bunlardan olağanüstü istidat gösteren öğrenciye yüksek öğrenim yollarını açık bulundurmak, öğretmen olamayacakları, öğrendiği işlerden birini yapmak üzere serbest köy hayatına bırakmak, öğretmen olacakları da köy hayatının koşullarına dayanabilecek ve o çevrede daha ileri ve verimli bir hayat yaratma gücünü kazanacak surette hazırlamak, öğretmeni ve köye gerekli elemanlar yetiştirmek üzere açılacak kuruluşları, arazi durumu elverişli yerlerde kurmak, onlart üretici birer kurum haline getirerek hiç olmazsa öğrencinin yiyeceğini sağlayabilecek şekilde yönetmek, böylelikle masraflarını azaltarak devlete yük olmayacak duruma gelmelerine çalışmak...”

Yasanın birinci maddesinde "Köy Öğretmeni ve diğer köy meslekleri erbabını yetiştirmek üzere Maarif Vekilliğince Köy Enstitüleri açılacă̆ı” hükme bağlanmaktadır. Yasaya göre, beş sınıflı köy okulunu bitiren sağlıklı ve yetenekli çocuklar seçilecek ve okullara kabul edileceklerdir. Bu okulları (enstitüleri) bitirip görevlerine atananların mecburi hizmet yılları yirmi yıldır. Mezunlar altı yıl sürecince $20 \mathrm{TL}$. maaş alacaklar ve bu maaş altıncı yil sonunda 30 TL. ve on beşinci yıl sonunda da 40 TL.'na yükseltilecektir. Öğretmenlere göreve başladıklarında bir kereye mahsus olmak üzere 60 TL. sermaye, tarım araç ve gereçleri ile ailesiyle geçimine yetecek arazinin devletçe verilmesi öngörülmektedir. Kanun maddesinde de açıkça görüleceği üzere, Enstitüler adeta birer tarım işletmesi biçiminde donatılıyorlardı ${ }^{21}$. Yasa tasarısının TBMM'de görüşülmesi sırasında Kâzım Karabekir, enstitülere yalnızca köy çocuklarının alınmasının ülkede kentli-köylü ayırımını doğuracağını öne sürerek, tasarıyı şu sözlerle şiddetle eleştirmiştir ${ }^{22}$ :

“...Parti programında sinıf ayırımı yok diyoruz ama onu elimizle yaratıyoruz... Biz şehir ve köy çocuklarını birbirleriyle kaynaştıracak yerde bir safiyeti fikriye ile ayırırsak sonra acaba bu köylere başka taraflardan yapılacak telkinlerle günün birinde biz bu şehirlilerin karşısında başka fikirlerle onları mücehhez bulmaz miyız?"

\footnotetext{
${ }^{21}$ A.g.e., s. 376.

${ }^{22}$ A.g.e., s. 376-377; Turan, s. 42.
} 
Milli Eğitim Bakanı Hasan Âli Yücel ise, bu eleştiriye şöyle karşılık vermiştir ${ }^{23}$ :

"Köy ilkokullarından gelen çocuklart şu veya bu şekilde tereddüde mahal vermeksizin imtihan ederek, karakterlerini yoklayarak ve bedeni kabiliyetlerine bakarak seçip enstitülere alacă̆ız... Bizim arzumuz köyün içerisinde bilgili, sihhatli, memleketine bağlı ve müstahsil vatandaş yetiştirmektir. Yoksa köylüyü bu arz ettiğim melekelerle techiz edip onları şehre akın eder vaziyete getirmek değildir... Mesele köylü çocuğunu hayat bakımından köylülük mahiyetini kaybetmeksizin yetiştirmektir. Bu davayı hiçbir zaman zayiflatmayalım... diyorum."

TBMM'ndeki bu görüşmeler sırasında tasarıyı savunanların açıklamalarına karşın, enstitülerin kurulmasına kimi milletvekillerinin içten karşı oldukları oylama sırasında belli olmuştur. 17 Nisan 1940 günü yapılan son oylamada 426 milletvekilinden 148'i oylamaya katılmamış ve tasarı 278 oyla kabul edilerek yasalaşmışı ${ }^{24}$. Tasarıya oy vermeyen milletvekilleri arasında Celal Bayar, Adnan Menderes, Fuat Köprülü de vardı. Gerekçeleri ise Kâzım Karabekir'in de dile getirdiği gibi, bu yasa ile köy-kent ayırımı yaratılacağı ya da yeni bir toplumsal sınıfın ortaya çıkabileceği kuşkusu hakim olmuştu. Ancak Milli Şef'e karşı cephe almamak için oylamaya katılmamışlardı ${ }^{25} .3803$ sayılı Köy Enstitüleri Kanunu'nda, “Köy Öğretmeni ve köye yarayan diğer meslek erbabını yetiştirmek üzere ziraat işlerine elverişli arazi bulunan yerlerde Maarif Vekilliği'nce [MEB] Köy Enstitüleri açılır." ibaresi yer almaktadır. Bu yasa hükmüne göre enstitülerin görevi sadece köy öğretmeni yetiştirmekle sınırlı olmayıp, öğretmenle birlikte sağlık görevlileri, teknisyenler gibi meslek elemanları yetiştirmekti ${ }^{26}$. Köy Enstitüleri Kanunu'nun 17 Nisan 1940 tarihli Cumhuriyet gazetesinde halka şöyle duyurulduğu görülmektedir ${ }^{27}$ :

"Köy Enstitüleri teșkili hakkındaki kanun layihası son șeklini aldl. Layihaya göre köy öğretmeni ve köye yarayan diğer meslek erbabı yetiştirmek üzere ziraat arazisine elverişli bulunan yerlerde Köy Enstitüleri açılacaktır. Köy Öğretmen Okullart bu layiha ile kanunlaştıktan sonra Köy Öğretmen Okullarına kaydolunacaklardır."

Köy Enstitüleri, II. Dünya Savaşı'nın sınıra dayandığı, ülkede kuraklık ve kıtlığın kol gezdiği bir dönemde kuruldu. Ülke kaynakları her yönden kısıtlı ve ürünün büyük kısmı da her an çıkacak savaş için ayrılıyordu.

\footnotetext{
${ }^{23}$ Çavdar, s. 375.

${ }^{24}$ Fay Kirby, Türkiye'de Köy Enstitüleri, İstanbul, İmece Yayınları, 1962, s.199-202; Turan, s. 42 .

${ }^{25}$ Köy Enstitülerinin kuruluşu ile ilgili kanun 22 Nisan 1940 tarihli olup, Kanun sayısı 3803'tür. Bkz. Kirby, s. 140.

${ }^{26}$ Niyazi Altunya, "Köy Enstitüleri" Bilim ve Aklın Aydınlı̆̆ında Eğitim Dergisi, Yıll: 3, No. 26, (Nisan 2002), s. 1.

s. ${ }^{27}$ Cumhuriyet Gazetesi "Yol ve Maarif Hareketleri”, Y11 16, No. 6726 (17 Nisan 1940),
} 
Ulusal Bağımsızlık Savaşı'ndan arta kalan çocukların oluşturduğu erkek iş gücü yeniden askere alınmış, köylerde kadın ve çocuklar kalmıştı. Dolayısıyla enstitüler "çocuk işgücü" ile kuruluyordu. Köylüler ise, tek dayanakları olan çocuklarını okula vermek istemiyorlardı. Hele kız çocuk bulmak çok zordu. Bir yandan da her bulaşıcı hastalık çocukları alıp götürüyordu. İşte bütün bu sıkıntılara rağmen Köy Enstitüleri'nde yapılan tarım sayesinde öğrencilerin ihtiyaçları fazlasıyla karşılanmış ve elde edilen üretim fazlasıyla köylüye ve devlete yardım edilebilmiştir. Enstitülerde kısa sürede yapımı gerçekleşen binalar ve öğrencilerin çabalarıyla sağlanan elektrik gücü, o dönem için anımsanamayacak başarılardır ${ }^{28}$.

İlk dönemlerdeki zorluklar aşılınca gerçekleştirilen sağlık memuru yetiştirme programı, önemli bir başarı olmuştur. Öyle ki bu programla hem enstitü öğrencilerinin sağlık ihtiyaçları karşılanırken, hem de köylülerin sağlık taramaları yapılmış ve gerekli tedaviler uygulanabilmiştir. Köy Enstitüleri'nde öğrenciye yetki ve sorumluluk verilerek onların kişiliğinin geliştirilmesine çalışılmış ve ileride köye gittikten sonra karşılaşacağı güçlükleri başarabilecek yetenekleri kazanması sağlanmıştır. Tüm bu özellikleri kazandıktan sonra köye öğretmen olarak giden Köy Enstitüsü mezunları, köylerde öğrencilerinden başlayarak aileye kadar ulaşan bir eğitim ortamı yaratmışlardır. Bu eğitim ortamı içinde düzenlenen kurslarla okuma-yazma ve meslek kazanmalarına yönelik eğitimi de vermişlerdir. Öğretmenler bu çalışmaları yaparken köyde yalnız olmamış, gezici öğretmen, gezici başöğretmen ve ilköğretim müfettişlerince denetlenmiş ve karşılaşılan sorunlar hep birlikte çözülmüştür ${ }^{29}$.

Cumhuriyetin aydınlanma hedefleri, ülke gerçekleri ve çağdaş eğitimbilimin verileri arasında yapılmış başarılı bir sentezin ürünü olan Köy Enstitüleri, köy insanının bilimin aydınlığında, bilinçli bir liderlikle kendi yazgısını değiştirmeye yönelik bir hareket olmuştur. Bu hareket, kendi ülkemizin beyin gücü, yaratıcılığı ve yurtseverliğinin örgütlenerek, toplumun en yoksul çocuklarının kendi emekleriyle ücretsiz öğrenim görebileceklerini, kıt olanaklarla da çağdaş eğitimin olabileceğini ve demokrasinin sözle değil, yaşanarak öğrenilebileceğini kanıtlamıştır ${ }^{30}$.

Köy Enstitüleri çalışmalarıyla kuruluş amaçlarının çok üstünde bir başarı göstermiş ve köyün, kırsal alandaki yaşayanların sorunlarını ortaya koyan ilerici bir kuşağın yetişmesini sağlamıştır. Köy Enstitülerinde yetişen yazarlar, düşünürler Türkiye insanına ufuk açan bir rol oynamışlardır. Mahmut Makal'in "Bizim Köy”ü, Fakir Baykurt'un "Yllanların Öcü",

${ }^{28}$ Mustafa Aydoğan, Hasan Âli Yücel, Köy Enstitüleri ve Köy Eğitimi Ile İlgili Yazıları, Konuşmaları, I. B., İstanbul, Köy Enstitüleri ve Çağdaş Eğitim Vakfı Yayınları, 1997, s. 1925 .

${ }^{29}$ A.g.e., s. 25-50.

${ }^{30}$ Sevket Gediklioğlu, Evreleri, Getirdikleri ve Yankilarıyla Köy Enstitüleri, Ankara, İs Mat. Tic., 1971, s. 241-250; İsmail Hakkı Tonguç, Canlandırılacak Köy, İstanbul, Remzi Kitabevi, 1947, s. 638-645. 
“Kaplumbağalar" ve "Tırpan”, Mehmet Başar'ın şiirleri, Talip Apaydın'ın öykü ve romanları akla gelen ilk örneklerdir ${ }^{31}$.

\section{Köy Enstitülerine Karşı Tepkiler}

Köy Enstitülerinin aleyhine yönelik propaganda ve eleştiriler 1943'te toplanan 2. Eğitim Şûrası'nda iyice ortaya çıkmaya başlamıştır. Bütün olumlu gelişmelere karşın Enstitülerdeki eğitim, öğretim ve köy okullarının yaptırılmasında karşılaşılan güçlükler kimi eleştirilere yol açmış ve bu eleştiriler giderek suçlamalara dönüşmüştür.

Değişik nedenlerden kaynaklanan bu eleştiri ve suçlamaları şu şekilde sıralamak mümkündür. Enstitülere yalnızca köy çocuklarının alınması ve mezunlarının da yine köylerde görevlendirilmesi, toplumda bir köylü-kentli ayrımı yani sınıf farklılı̆̆ doğurmaktadır. Bu bölünme Anayasaya da girmiş olan Halkçılık ilkesine ve anlayışına da ters düşmektedir. Enstitülerde aşırı solcu, hatta komünist ideolojiyi yansıtan bir eğitim ve öğretim yapılmaktadır. Öğrencilerin okul yapımlarında, tarım ve teknik uygulamalarında, temizlik ve bakım işlerinde çalıştırılmaları Sovyet Rusya'yı ve komünist rejimleri andırmaktadır. Bu tür eğitim Milliyetçilik ilkesiyle çelişmektedir. Enstitülerin yönetim kadrosu genelde solcu, Marksist tanınan kişilerce doldurulmuştur. Yatılı olan Enstitülerde uygulanan karma öğretim, yani kız-erkek beraberlikleri, Türk aile ve ahlâk anlayışına uymamaktadır. Okul, işlik, öğretmen evi yapımında ve çocuklarını okula göndermede köylülere getirilen yükümlülükler, son derece ağır olup özellikle yurdun ulaşımı güç bölgelerinde tek tip okul binası projesinin uygulanması yapım giderlerini daha da artırmaktadır. Bu yükümlülükler Anayasanın eşitlik ilkesine de aykırıdır ${ }^{32}$.

Köy Enstitülerine karşı olanlar, özellikle üniversitelerdeki sağ-sol olaylarını bahane ederek, Köy Enstitülerini bu akımlardan korumak gerektiğini belirtiyorlardı. Enstitülerdeki üretici eğitimi de eleştirerek, milliyetçilik ve gelenekçilik yönünden eksikliklerinin bulunduğu söyleniyor ve II. Dünya Savaşı'nın ülkede yarattı̆̆ı bunalımı bile eğitim yanlışına bağlıyorlardı. Özellikle İkinci Eğitim Şûrası'nda bu eleştirileri getirenler, Köy Enstitülerini yakından tanımayan, ön yargılı fikirlere sahip dinci ve mutaassıp gruptu ${ }^{33}$. İtirazlardan biri de köylünün okumasının "gözzünün açılmasının" doğru olup olmadığını ileri süren gerici zümre ve eskiden beri köylünün sırtından geçinen ağalard1 ${ }^{34}$. Milliyetçilik diye tutturan, Köy Enstitüleri'nde Atatürk ilkelerinin öğretilmesini, öğrenciye yetki ve

\footnotetext{
${ }^{31}$ Çavdar, Türkiye'nin Demokrasi Tarihi, s. 376-377.

${ }^{32}$ Turan, s. 46-47.

${ }^{33}$ Türkoğlu, s. 492.

${ }^{34}$ Ahmet Emin Yalman, Yarının Türkiyesi'ne Seyahat, İstanbul, Cem Yayınları, 1990, s.
} 25 
sorumluluk verilerek uygulanan demokratik eğitimi aşırı bulanlardan birisi de Reşat Şemsettin Sirer'dirr ${ }^{35}$.

Köy Enstitüleri'ne yöneltilen eleştirilerden birisi de uygulanan karma eğitimdir. Dinci kesim bir öğrencinin bir kız öğrenciye, onu evlenmeye zorlayan mektup yazdığ namuslarının ayaklar altına alındığı gibi eleştiriler öne sürüyorlardı. Adı geçen enstitüler köy kızları için yurt çapında açılmış kapılardı. Yapılan eleştirilerin amacı Köy Enstitüleri'nin düzeninin bozulmasına zemin hazırlamaktı. Yapılan eleştiriler sonucu kız öğrenciler bir-iki enstitüde toplanmış ve karalama yoluyla beklenen sonuç sağlanmıştır ${ }^{36}$. Enstitülerdeki karma eğitimi eleştiren taassup grup, kız öğrencilerin pantolon-ceket giymesini de eleştirerek komünist modası olduğunu iddia etmişlerdir. $\mathrm{Bu}$ eleştirileri yapanlar köy kızlarını sömüremeyeceğini, amaçları doğrultusunda kullanamayacaklarını düşünen kişilerdi ${ }^{37}$.

Köy Enstitüleri'ne karşı yapılan eleştirilerden biri de zararlı yayın diye nitelendirilen Köy Enstitüleri dergisi, kitaplıklarda bulunan yabancı dillerden çevrilmiş klasikler ve öğretmenlerin konuşmalarına dayanarak ortaya atılan komünizm propagandası olmuştur. Enstitülerde din düşmanlığı işlendiği, din derslerinin konmadı ̆̆ 1 ve bir bayan öğretmenin "Allah ile devlet olmasa beşeriyet saadete kavuşur" dediği iddia edilmişti ${ }^{38}$. Köy Enstitüleriyle köylerdeki canlanma ve eski alışkanlıkları yıkma çabası Köy Enstitüleri'nin sonunu hazırlamıştır.

Köy Enstitüleri ile fakir çocukların okuması, köylüyü uyandırması ve köylerde yıllarca süregelen ağalık düzenini sorgulaması bir korku yaratmaya başlamıştı. Bunun olsa olsa Rusya'da olabileceği düşüncesiyle Enstitülere karşı kötüleme kampanyasıyla "din elden gidiyor" feryadını koparan kişiler, çıkarlarını tehlikede gören politikacılar, köyden kente ve Ankara'ya uzanan karalamalarını Çankaya'ya kadar ulaştırarak Köy Enstitüleri'nin kapatılmasına zemin hazırlamışlardır ${ }^{39}$.

Bütün bu eleştirilere rağmen Enstitüler çalışmalarına devam ediyor, Cumhurbaşkanı İnönü her eleştiri karşısında İsmail Hakkı Tonguç’a destek veriyor ve Enstitülere daha fazla kız öğrenci alınması için onu sıkıştırıyordu. Ancak eleştiriler her geçen gün artıyordu. O günlerde ülkeye demokrasi fikrinin gelmesi siyasi açıdan karışıklıklara sebep olmuş ve CHP

${ }^{35}$ I. Eğitim Şûrası'nda Tonguç'un hazırladığı "Köyde Eğitim Raporu”na da karşı çıkmıştı. Eğitimci ve siyaset adamı olan Sirer, Yüksek öğrenimini tamamladıktan sonra 1943 'ten ölümüne kadar (1953) Sivas Milletvekili olarak Meclis'te bulunmuştur. Recep Peker Hükümeti'nde 1946-1948 arasında Milli Eğitim Bakanlığı ve bir ara da Çalıșma Bakanlığı yapmıştır. Milli Eğitim Bakanı iken Köy Enstitüleri'nin kapatılmasında etkin rol oynamıştır. Büyük Larousse Sözlük ve Ansiklopedisi, "Reşat Şemsettin Sirer" maddesi, C. XX, (İstanbul 1986), s. 10584

${ }^{6}$ Şevket Gediklioğlu, Türkiye’de Yaygın Eğitimden Çăgdaş Eğitime, Ankara, Kadığlu Matbaasi, 1991, s. 289-290.

${ }^{37}$ Türkoğlu, s. 496.

${ }^{38}$ Gediklioğlu, s. 496.

${ }^{39}$ Hadi İlbaș "Bu Korku Neden", Imece Dergisi, C. II, No. 11 (Mart 1962), s. 82-89. 
zayıflamıştı. İkinci Dünya Savaşı'ndan sonra çok partili siyasi hayata geçiş çalışmaları, Ulusal Bağımsızlık Savaşı'nda Atatürk'ün yanında olan ve partisine giren bazı kişiler, içten içe Atatürk'ün eylem ve fikirlerini zayıflatmak için uygun ortam bekliyorlardı. Bir zamanlar Atatürk'ün yanında yer almakla birlikte, O'nun birçok ilkesine karşı çıkan General Kâzım Karabekir, Reşat Şemsettin Sirer, Tonguç ve Yücel'e karşı partinin sağ kanadında yer alarak Köy Enstitüleri'ne karşı olan politikanın başını çekmeye başlamışlardı ${ }^{40}$.

1945 'te çok partili siyasal hayata geçişle birlikte CHP'nin karşısında birçok siyasi partinin kurulması, enstitülere yöneltilen suçlamaları da arttırmıştır. Karşıt partiler arasında özelikle Demokrat Parti, CHP yönetimini yıpratmak için Köy Enstitüleri'ni bir koz olarak kullanmaya başlamıştı. İşin ilginç yanı, suçlamaların CHP içinden de taraftar bulmasıdır ${ }^{41}$. 21 Temmuz 1946 genel seçimlerinden sonra partideki sağ kesim hem parti içinde kalmış hem de partiye ve çevreye karşı yeni bir tavır içine girmişti. Sağ kesim, DP'ye karşı olmak amacıyla partiyi sağa kaydırmada birleşmişlerdi. Demokrat Parti, CHP'yi ve özellikle Köy Enstitüleri'ni eleştiriyor, CHP ise bunların halkın yararına olduğunu anlatmak yerine "düzelteceğiz" diyerek kendi yaptıklarını savunamiyordu ${ }^{42}$.

5 Ağustos 1946'da Büyük Millet Meclisi açılmış ve 7 Ağustos'ta da sağ eğilimli "Recep Peker Kabinesi" kurulmuştur. Yeni hükümet'te ise Hasan Âli Yücel'in yerine Milli Eğitim Bakanlığı'na Reşat Şemsettin Sirer getirilmişti ${ }^{43}$.

Yeni Milli Eğitim Bakanı'nın ilk icraatı, Köy Enstitüleri'nin kurulmasında büyük payı bulunan ve enstitülerce " $b a b a$ " ünvanıyla tanınan İsmail Hakkı Tonguç’u İlköğretim Genel Müdürlügü'nden uzaklaştırmak olmuştur. Sirer'in amac1, Köy Enstitüleri'ni kendi “milli" görüşüne uydurarak değiştirmekti. Onun düşüncesine göre Tonguç, Enstitüler konusunda İnönü'yü kandırmıştı. Nitekim, önce Talim ve Terbiye Kurulu'na atanan Tonguç, çok geçmeden bir ortaokulun resim öğretmenliğine gönderilecektir. Bunu "solcu-Tonguçcu" olarak tanınan Enstitü yöneticileri ile öğretmenlerin görevden alınıp, başka yerlere ya da birimlere atanmaları izlemiştir $^{44}$.

Enstitülerdeki bu tasfiye hareketi olanca hızıyla devam ederken, suçlamalarda da önemli oranlarda artışlar göze çarpmaktadır. Çifteler

\footnotetext{
${ }^{40}$ Türkoğlu, s. 496.

${ }^{41}$ Turan, s. 48.

${ }^{42}$ Türkoğlu, s. 503

${ }^{43}$ Cumhuriyet Gazetesi, "Recep Peker Kabinesi”, Y11: 23, No. 7894, (7 Ağustos 1946), s. 2 .

${ }^{44}$ Reşat Şemsettin Sirer'in Demokrat Parti'nin iktidarı sırasında, 11 Kasım 1951'de TBMM'nin gizli oturumunda Enstitüler konusunda yapılan görüşmelerde "Tonguç Baba' $y$ t defederken hiçbir mukavemetle karşılasmadım... Icraatıma devam ederken 500 kişilik kadrodan 400 kişiyi ayırırken hiçbir taraftan güçlük görmedim..." şeklindeki konuşması son derece ilginçtir. Bkz. Turan, s. 49-50; Kurçak, s. 304.
} 
Enstitüsü'nde komünistlerin bir şebeke kurduğu, Hasanoğlan Yüksek Enstitüsü'nde komünist öğrencilerin bulunduğu ihbarları birbirini izliyordu. Bu yüzden Enstitü mezunlarından bir kısmı yedek subay okullarından er olarak çıkartılmışlardır. Enstitü öğrencileri arasında sağcı-solcu, milliyetçikomünist ve ilerici-gerici ayrımı ve sürtüşmeleri de baş göstermiştir. Enstitülerde komünizm propagandası yapıldığı yolundaki suçlamalara Fevzi Çakmak Paşa'nın da katılması, Hasan Âli Yücel-Kenan Öner davasına yol açmıştı ${ }^{45}$.

Köy Enstitüleri ile ilgili değişiklikler bununla da kalmamış 1947'de ilgili yasa ve yönetmeliklerde yapılan düzenlemelerle, sistemin işleyişi adeta durdurulmuştur. 4274 ve 5210 sayılı yasalarla köy okullarının öğretmen sağlık memuru ve ebe evlerinin yapımlarının devletçe üstlenilmesi kabul edilmiş, enstitülere verilen canlı ve cansız tüm demirbaşlar, donanım araçları geri alınmış ve bunların dışında Hasanoğlan'daki Yüksek Köy Enstitüsüi ile bütün eğitmen kursları kapatılmıştır. Mevcut olan sağlık kollarının sayısı bire indirilen enstitülerin öğretim programlarında yeni düzenlemelere gidilmiştir. Milli Eğitim Bakanı Reşat Şemsettin Sirer, Köy Enstitülerini kuruluşlarında öngörülen sistemin dışına çıkartırken, muhalefetteki Demokratik Parti'nin de desteğine dayanmıştır. Enstitülerin kaderi Sirer'in uygulamalarıyla belli olmuştu.

CHP iktidarının son hükümeti olan Şemsettin Günaltay kabinesinde Milli Eğitim Bakanlığı'nı üstlenen Tahsin Banguoğlu döneminde ise, 1949 'da çıkartılan 5541 sayılı yasa ile enstitülere yalnızca köy çocukların alınması yönteminden vazgeçilmiştir. Bundan böyle köy çocuklarının yanında $1 / 4$ oranında belediyesi bulunan kasabalardaki ilkokul mezunları da enstitülere alınıyor ve enstitülerdeki karma eğitime son veriliyordu ${ }^{46}$. Nitekim, 5210 sayılı yasa ile eğitimde inisiyatifi ele alan İçişleri Bakanlığı, seçimleri kazanma gayesiyle ilkokullara din dersi koymuş ve Enstitü mezunları din politikacılarının hedefi olmuşlardır. Böylece, 1938-1940 yıllarında Köy Enstitüsü sistemini ilköğretim sorununu kesin olarak çözecek bir model diye uygulamaya koyan CHP hükümetleri ve onun savunucusu Milli Şef İsmet İnönü, 1946'dan başlayan ve son dört yıllık yönetimlerinde adım adım bu sistemi kaldırmaya yönelmiş görünüyorlardı. Bunda da çok partili yaşama geçildikten sonra enstitülere ilişkin eleştiri ve suçlamaların daha da artması, öte yandan İnönü'nün milli şef gücünü yitirmesinin ve CHP'de sağ eğilimli çevrelerin güç kazanmasının kuşkusuz büyük etkisi vardır. Bu gelişmelerle atılan geri adımlardan sonra, 1950'de iktidara gelen

${ }^{45}$ Bağımsız Milletvekili Fevzi Çakmak, "solcuları koruyanın Halk Partili bir eski Milli Ĕgitim Bakanı olduğunu" ileri sürmüş, bunun üzerine Hasan Âli Yücel, 5 Şubat 1947'de Ulus gazetesinde yazdığı yazıda, "Bu ben miyim" diye sorunca, cevabı Fevzi Paşa yerine DP İstanbul Îl Başkanı Kenan Öner, "Evet sensin" diyerek Yücel'i komünistleri korumak ve komünizmin yayılmasına yardımcı olmakla suçlamıştır. Yücel ise haksızlığa uğradığı gerekçesiyle Kenan Öner aleyhine dava açmıştır. Ankara Üniversitesi profesörlerinden Bülent Nuri Esen'i de avukat olarak tutmuştur. Bu dava hakkında geniş bilgi için bkz: Hasan Âli Yücel, Davam, Ankara, Ulus Basımevi, 1947.

${ }^{46}$ Türkoğlu, s. 513-515; Turan, s. 50. 
Demokrat Parti döneminde Köy Enstitüleri'nin tamamen kapatılması zor olmamıștır ${ }^{47}$.

DP'nin ilk kabinesinde Milli Eğitim Bakanı olarak görev alan Tevfik İleri döneminde çıkarılan 27 Ocak 1954 gün ve 6234 sayılı kanunla, "Köy Enstitüleri” bütünüyle öğretmen okullarına dönüştürülerek kapatılmışlardı4 ${ }^{48}$. Böylece bir eğitim mücadelesi de sonuçlandırılmış oluyordu.

\section{Sonuç}

Köy Enstitüleri'ni, Türkiye'yi Atatürk Devrimleri'nin Türkiyesi yapmayı hedefleyen eğitim kurumları olarak değerlendirebiliriz. Köy Enstitüleriyle ekonomik ve toplumsal kalkınma birlikte hedeflenmiş ve Türk köylüsünün üzerindeki bilgisizlik, cahillik örtüsü kaldırılmaya çalışılmıştır. Çünkü okuryazar olmayan bir toplum ile Köy Enstitüleri'nin hedefi olan çağdaş uygarlığa ulaşılamazdı. İşte Köy Enstitüleri ile bu eksiklik giderilmeye çalışılmıştır.

\section{KAYNAKÇA}

Altunya, Niyazi, "Köy Enstitüleri" Bilim ve Aklın Aydınlı̆̆ında Eğitim Dergisi, Y11: 3, No. 26, (Nisan 2002).

Aydoğan, Mustafa, Hasan Âli Yücel, Köy Enstitüleri ve Köy Eğitimi Ille İlgili Yazıları, Konuşmaları, I. B., İstanbul, Köy Enstitüleri ve Çağdaş Eğitim Vakfı Yayınları, 1997.

Bucak, Esengül Balcı, Türkiye'nin Eğitim Politikaları ve Siyasi Parti Ödülleri, Ankara, Adım Yayınları, 1993.

Büyük Larousse Sözlük ve Ansiklopedisi, "Reşat Şemsettin Sirer" maddesi, C. XX, (İstanbul, 1986), s. 10584.

Cumhuriyet Gazetesi "Yol ve Maarif Hareketleri", Y1l 16, No. 6726 (17 Nisan 1940), s. 2.

., "Köy Enstitüleri İle İlköğretim Okulları Birleștirildi”, Yıl. 29, No. 10596, (28 Ocak 1954), s. 7.

"Recep Peker Kabinesi”, Yıl: 23, No. 7894, (7 Ağustos 1946), s. 2.

., "Köy Enstitüleri ve Açllacak Yerler", Yıl: 16, No. 6727 (18 Nisan 1940), s. 1.

Çavdar, Tevfik, Türkiye'nin Demokrasi Tarihi 1839-1950, 2. B., Ankara, İmge Kitabevi, 1999.

Çeçen, Anıl, "Halkevleri", Atatürk ve Halk Evleri, Ankara, TTK Yay., 1974.

${ }^{47}$ Turan, s. 51.

${ }^{48}$ Cumhuriyet, "Köy Enstitüleri İle İlköğretim Okulları Birlestirildi”, 28 Ocak 1954, Y1l. 29, No. 10596, s. 7; Necdet Sakaoğlu, Cumhuriyet Dönemi Eğitim Tarihi, İstanbul, Cep Üniversitesi İletişim Yay., 1993, s. 115. 
Çıkar, Mustafa, Hasan Âli Yücel ve Türk Kültür Reformu, Ankara, Türkiye İş Bankası Kültür Yayınları, 1997.

Doğramacı, İhsan, “Atatürk ve Eğitim”, Atatürk Araştırmaları Merkezi Dergisi, C. I, No. 3, (Temmuz, 1985).

Gediklioğlu, Şevket, Evreleri, Getirdikleri ve Yankılarıyla Köy Enstitüleri, Ankara, İş Mat. Tic., 1971.

Türkiye'de Yaygın Eğitimden Çă̆daş Eğitime, Ankara, Kadığlu Matbaası, 1991.

Genelkurmay Başkanlığı, Atatürkçülük, Atatürkçü Düşünce Sistemi, İstanbul, Milli Eğitim Bakanlığı Yayınları, 1998.

Hakimiyet-i Milliye Gazetesi, 20 Şubat 1932, s. 2.

İlbaş, Hadi, "Bu Korku Neden”, İmece Dergisi, C. II, No. 11 (Mart 1962).

İnan, Rauf, "Türkiye Cumhuriyeti ve Eğitim (Bir Yokluktan Bir Atılıma)”, Atatürk Konferanslarl (1973-1974), Ankara, TTK, 1977.

Atatürkçü Destansal Milli Eğitim Bakanı Hasan Âli Yücel, I. B., Ankara, Eğit-Der. Yayınları, 1995.

Kirby, Fay, Türkiye’de Köy Enstitüleri, İstanbul, İmece Yayınları, 1962.

Sakaoğlu, Necdet, Cumhuriyet Dönemi Ĕ̆itim Tarihi, İstanbul, Cep Üniversitesi İletişim Yayınları, 1993.

Sorguç, Bahir, 1920'den 1981'e Milli Ĕ̆itim Bakanlı̆̆ı, İstanbul, MEB Yayınları, 1982.

TBMM Zabit Ceridesi, I. Dönem, 3. Toplantı, C. 188, s. 5.

Tonguç, İsmail Hakkı, Canlandırılacak Köy, İstanbul, Remzi Kitabevi, 1947. İlköğretim Kavramı, İstanbul, Remzi Kitabevi, 1946.

Turan, Şerafettin, Türk Devrim Tarihi, 4. Kitap, Ankara, Bilgi Yayınevi, 1999.

Türkoğlu, Pakize, Tonguç ve Enstitüleri, İstanbul, Yapı ve Kredi Yayınları, 1997.

Yalman, Ahmet Emin, Yarının Türkiyesi'ne Seyahat, İstanbul Cem Yayınları, 1990.

Yücel, Hasan Âli, Davam, Ankara, Ulus Basımevi, 1947. 